\title{
CUSTOMER RELATIONSHIP MANAGEMENT IN SMALL AND MEDIUM-SIZED ENTERPRISES OF THE MORAVIAN-SILESIAN REGION: QUALITATIVE RESEARCH
}

\author{
[Řízení vztahů se zákazníky v malých a středních podnicích v \\ Moravskoslezském kraji: kvalitativní výzkum] \\ Adéla Chromčáková ${ }^{1}$, Halina Starzyczná ${ }^{2}$ \\ ${ }^{1}$ Silesian University, School of Business Administration, Univerzitni nám. 1934/3, 73340 Karviná \\ Email: chromcakova@opf.slu.cz \\ ${ }^{2}$ Silesian University, School of Business Administration, Univerzitni nám. 1934/3, 73340 Karviná, \\ Email: strarzyczna@opf.slu.cz
}

\begin{abstract}
Customer relationship management (CRM) is in the centre of attention of companies of any size and it is applied in different areas of national economy. In the School of Business Administration in Karviná the CRM research is being carried out since 2005 under a grant and other projects. The objective of this article is to introduce partial results of the latest research carried out especially under "Student Grant Competition" (2017-2019) or under the project of long-term sustainability OP VK (2014-2019). The particular objective of this contribution is to introduce brief conclusions of the interviews we had with representatives of small and medium sized enterprises (SME) in the MoravianSilesian Region. These interviews were a necessary part of the pre-research phase of our qualitative research. Our research topic is connected with the main problem areas of CRM in the MoravianSilesian Region.
\end{abstract}

Keywords: Customer relationship management, CRM definition, CRM architecture, CRM elements, CRM benefits and barriers, CRM in SME.

JEL classification: M31

Received: 1.10.2018; Reviewed: 30.1.2019; 17.6.2019; Accepted: 19.6.2019

\section{Introduction}

Currently CRM is a frequently discussed topic. It is a part of marketing managed by a company focused on customers. Kotler et al (2007) mention a customer-oriented company and he perceives it as a company endeavouring to provide higher value to its customers. It is possible thanks to the fact that when such company implements new marketing strategies, it still watches the customer development very carefully.

The aim of CRM is to build relations with customers, develop and maintain them. In the long term, companies try to build good relationships with regular customers because it is believed that regular customers are loyal customers. The significance of the loyal customer is priceless because a satisfied customer having a good relationship with a company contributes to the good and respected reputation of the company. It is CRM which helps a company to build relationships with customers and which helps to interconnect human resources, company processes and technologies.

In the School of Business Administration in Karviná the CRM research is being carried out continuously. Research teams deal with many CRM problem areas. The objectives of this article are to introduce the theoretical debate about CRM and to introduce partial results obtained from the semi-standardised interviews with representatives of chosen enterprises. The subject of this research is the area of CRM, its bases, the bigger picture such as loyalty of 
customers and technological aspects. The objects of the research are small and medium-sized enterprises.

\section{Current knowledge and CRM}

In the following part, we will pay attention to the important issues connected with CRM. These are as follows: marketing and CRM, definitions of CRM, its architecture, parts and elements.

\subsection{Marketing and CRM}

In 1960s Levitt emphasized that a goal of each company in the market should be meeting its customer needs. A marketing oriented company focuses on the customers, their wishes and needs. Later many authors started to deal with this idea and gradually developed it. Day and Wensley (1983) followed this idea up and elaborated it. They defined CRM as a system providing useful and needed information about customers. This information is especially useful when quotations are being created because quotes can then better fit customer needs and therefore the customer is likely going to be more satisfied. It can also positively influence the customer long-term relationship with the company. Afterwards the company can profit from gaining of a loyal customer.

The practical development shows that for companies it is necessary to build and manage customer relationships based on excellent knowledge of this area. So, information about customers are regularly registered, checked, analysed and appraised. All these activities are realized within CRM. But it is also important to notice that in marketing there had been a certain historical development preceding CRM. Meffert (1996) states that the development of marketing can be categorized into several stages. Starzyczná, Kauerová, Pellešová, Svobodová et al (2007) claim that before marketing developed, companies oriented mainly on production and sales.

The first marketing activities, called transaction or tradition marketing, related to branded products and market segmentation, appeared in 1950s. ${ }^{1} 1960 \mathrm{~s}$ are connected with own marketing. Subsequently, companies started to take the customer needs into account and gradually introduced marketing mix and SWOT analysis. Marketing mix, which was gradually modified, started to be used in various sectors of the national economy. 1980s were another significant step in the development of marketing. It was a period of a negative economic development due to oil shocks. 1990s are typical of the so-called long-term marketing. Marketing started to be perceived as an equal function of companies as well as an important part of management. It happened because customers stopped being interested only in the purchase as such but started to demand a complex service connected with the product they were buying. Hence, companies realized that they could not focus only on production but had to build relationships with suppliers, purchasers, mediators and customers. Companies also realized that the previously mentioned activities should be carried out through all stages of logistic chain.

So, this is a development which resulted in the shift of companies from transaction to relationship marketing ${ }^{2}$ - the reason is that customer preferences changed. Now a customer is focused on value. In 1990s this development was typical of the most market economies. Nonetheless, of course we cannot precisely say that this stage of marketing was going on in

\footnotetext{
${ }^{1}$ Transaction marketing focuses on efficiency of processes and on product. It represents a distribution function.

${ }^{2}$ It was originally published by A. Payne, see Dohnal (2006, p. 32).
} 
all countries at the same time. For instance in the Czech Republic marketing was introduced at the beginning of 1990s - so all phases of marketing development were delayed there.

CRM is a part of a wider concept of relationship marketing, which involves creation of relationships not only with customers but also with other partners. In 1991 Christopher, Payne and Ballantyn (2002) introduced their model of 6 markets. This model includes a customer market, supplier market, internal market, referral market, influence market and recruitment market. Nevertheless, in practise it is very common that a company focuses only on the customer market and CRM. Kotler et al (2007) define relationship marketing as a process of creation, maintenance and widening of valuable relationships with customers and other partners.

\subsection{CRM definition}

Many CRM definitions can be found in scientific literature. So, it is impossible to introduce here all of them. Nevertheless, it is worth mentioning that the CRM definitions include many similar terms. Most definitions mention strategic concepts. Individual definitions can differ by its approach to CRM, even though its key words are the same. The beginning of customer relationship is connected with technologies and software. Greenberg (2001) points out that technologies are crucial for CRM implementation as well as for improvement of these processes.

CRM uses sophisticated software and analytical tools sorting information about customers from all available resources and enabling the use of the given results for the purpose of strengthening of relationships with customers (Kotler, Armstrong 2004). Dohnal (2002) sees CRM not only as an activity of building and strengthening of relationships with customers, but also as all company processes and IS/ICT technologies. He saw the main objective of CRM in the maximization of customer loyalty and company profitability. CRM processes and their integration was a subject of research of many other authors (for instance Payne and Frow 2004, Chlebovský 2005). In many definitions, authors emphasize the strategic part of CRM and its long-termness (Payne 2007). Even Starzyczná, Kauerová, Pellešová, Svobodová et al (2007) point out the importance of strategic part of CRM and add that CRM can be also perceived as a competitive advantage of companies.

The latest definitions see CRM especially as the process or as some value, which is important for a customer, or vice versa the value which a customer has for a company. Kotler and Keller (2013) perceive CRM in a broader context and emphasize that for a company it is very important to know their customers for two main reasons: first it contributes to better mutual contact between a company and its customers and second it can help to strengthen customer loyalty. Buttle a Maklan (2015) find CRM to be the main business strategy, that integrates processes, functions and external networks, and which brings value for targeted customers. This strategy uses high quality information, which was collected by companies and via information technologies. Kumar and Rainartz (2016) emphasize value both in marketing and in CRM. They assume that creation of value in marketing has two dimensions. On the one hand, companies create value for its customers and on the other hand, customers create value for companies. According to Loštáková et al (2009), value management should deal with value and its creation. Kuman, who is the most cited author in the field of CRM, focuses on lifelong customer value, customer needs and long-term customer relationships. Table 1 presents definitions of CRM from various authors. 
Table 1: CRM definition from different perspectives

\begin{tabular}{|l|c|}
\hline \multicolumn{1}{|c|}{ CRM Definition } & Author \\
\hline $\begin{array}{l}\text { A method using software and technologies for automatic control and process } \\
\text { improvement }\end{array}$ & Greenberg 2001 \\
\hline $\begin{array}{l}\text { CRM includes employees, company processes, IS/ICT technologies with the main } \\
\text { objective to maximize customer loyalty and thereby company profitability }\end{array}$ & Dohnal 2002 \\
\hline A universal process how to keep useful customers & Payne, Frow 2004 \\
\hline $\begin{array}{l}\text { CRM is understood as a special software program and analytical technique serving for } \\
\text { integration and use of large databases about individual customers }\end{array}$ & Kotler, Armstrong \\
\hline $\begin{array}{l}\text { CRM is an interactive process that aims to achieve the optimal balance between a } \\
\text { company investment and customer satisfaction, where the optimal balance is } \\
\text { determined by the profit gained of both parties }\end{array}$ & Chlebovský 2005 \\
\hline $\begin{array}{l}\text { CRM is a strategic process that aims to develop good relationships with customers and } \\
\text { customer groups and thus CRM creates bigger value for shareholders }\end{array}$ & Payne 2007 \\
\hline $\begin{array}{l}\text { The purpose of CRM is to get known strategic customers and to create long-term } \\
\text { relationships with them, instead of endeavour to maximize short-term incomes }\end{array}$ & Lehtinen 2007 \\
\hline $\begin{array}{l}\text { CRM is a main business strategy which integrates internal processes and functions as } \\
\text { well as external networks. It creates and brings added-value for profitable customers } \\
\text { and is based on high-quality information about customers. CRM mediated by } \\
\text { information technologies }\end{array}$ & Buttle, Maklan \\
\hline
\end{tabular}

Source: authors' work.

The necessity and importance of CRM is emphasized in many definitions. Good and high quality CRM affects aspects of value connected with customers. Now let's deal with the architecture of the system.

\section{CRM architecture}

Many authors classify the CRM architecture into three parts: an analytic part, operative and collaborative parts (Dohnal 2002, Peelen 2005, Torggler 2008, Buttle 2009). Our previous research in the School of Business Administration in Karviná also confirmed the importance of the strategic level of CRM (Starzyczná, Kauerová, Pellešová, Svobodová et al. 2007). Buttle and Maklan (2015) also confirms the magnitude of the strategic level of CRM.

\section{Analytical part of CRM}

In the analytical part, we focus on analysis of customer data, their evaluation and presumptive customer buying behaviour. Companies try to collect all available customer data. Their analytical activities are associated with data mining. Data mining is used in the areas like market segmentation, cluster analysis, customer value analysis, and in other areas analyzing customer behaviour, needs and satisfaction (Hommer 2012, Buttle and Maklan 2015). These analyses enable us to characterize key customer groups, their attitudes and preferences (Reicher and Szeghegyi 2015).

\section{Operative part of CRM}

Automation, support and improvement of all company processes can be included into the operative part of CRM. It deals with issues related to contacting customers and with all activities connected with finding and keeping new customers. Payn and Frow (2013) believe that this part of CRM is the most developed one. Kotler and Keller (2013) deal with database marketing, which offers database useful for making contact with customers, making transactions and creation of necessary relationships. Buttle and Maklan (2015) state that in the scientific literature, the general automation of business processes, including the sale of goods, services and marketing, is referred as sales force automation (SFA). Nowadays the term "omnichannel" is also used when speaking of CRM. Marketing 4.0 mentions omnichannel (Kotler, Kartajaya a Setiawan 2016). Companies combine multiple communication channels: 
shopping search engines, banner campaigns, social networks, e-mails or messages are often used. On the other hand, during offline contact, companies frequently use tools like product flyers, shop windows, billboards etc. ${ }^{3}$ It is also important to note that the operative part of $\mathrm{CRM}$ is closely related to the collaborative part and sometimes they even overlap each other.

\section{Collaborative part of CRM}

The main purpose of this CRM part is sharing information gained from individual company departments: from all communication channels and systems. The collaborative part of CRM interconnects relationships between a company, sales and customers as well as relationships between a company and its employees (Payne 2007). The optimization of all processes is supported by suitable technologies and software (Buttle 2009). The important parts of the collaborative CRM are eCRM and the internet - eCRM refers to the use of e-commerce tools and the use of electronic distribution channels (Torggler 2008). Torggler (2008) classifies the collaborative CRM into the three following parts: first, customer contact management, second, eCRM and third, internet and customer interaction centre.

\section{Strategic part of CRM}

This area has been researched under a grant project carried out by the School of Business Administration in Karviná and the Faculty of Economics, VSB-TU Ostrava in 2005-2007. The project's focus was strategic marketing (Starzyczná, Kauerová, Pellešová et al. 2007). Of course, the strategic approach to CRM was researched by many other authors. It was revealed that the strategic part of CRM is connected with analytical, operative and collaborative CRM. Its output shall be a value added for both a customer and a company (Buttle, Maklan 2015). Payne (2007) or Greenberg (2010) assume that a customer strategy shall be integral to a marketing-oriented company.

Some authors, e.g. Payne a Frow (2013), Buttle and Maklan (2015) or Loštáková (2017), point out that the strategic part of CRM contributes to the development and access to CRM. It also results in building long-term relationships with customers and thereby it is beneficial for both customers and shareholders too (Payne a Frow 2013, Buttle a Maklan 2015 or Lošt'áková 2017).

\section{CRM elements}

CRM system consists of three main elements: people, technologies and processes (Wessling 2002, Dohnal 2002, Payne 2007, Buttle 2009, Coltman et al. 2011). In CRM people have a significant role. Their role can be either positive or negative. In terms of CRM, we define people as company employees, suppliers or customers. Customers are co-creators of value, this is especially valid in the sector of services, and they can influence the quality of provided services (e.g. a spectator of some performance also influences the atmosphere of the performance). SME have a specific position in customer relationship management. It is connected with the fact that from all types of companies, SME are the closest to the customer. Therefore, SME can have the closest mutual relationship with their customers what can be their vital competitive advantage (Chromčáková, Starzyczná, Stoklasa 2017). Fickel (1999) highlights the linkage of front-line employees (front office), from either the trade department, the marketing department, or the customer service department, and administrative employees (back office) with other company departments, i.e. the financial department, the logistics department, human resources department etc.

\footnotetext{
3 Penkala. Úvod do omnichannel. Proč je budoucností prodeje? [online]. [2018-07-25]. Available from: https://blog.acomware.cz/uvod-do-omnichannel-proc-je-budoucnosti-prodeje/.
} 
Technologies and process elements play an important role in the successful implementation of CRM. Technological media support the interconnection of all CRM elements with individual parts of companies. The amount and quality of technology facilities depend on the level of CRM processes. Here we cannot omit the previously mentioned database marketing. To contact their customers, companies can use a wide range of ways, e.g. through the internet, call centres, e-mails, mobile phones etc. Enterprises can also use multichannel access, i.e. omnichannel. Marketing oriented companies strive to integrate marketing and all related company processes to ensure that everything is subordinated to customer needs (Wesling 2002).

\section{Realization of qualitative research}

Within our research activities, we carried out a qualitative research. We prepared a semistandardised interview, which we see as a pre-research for our subsequent quantitative research of the main CRM problem areas. The general objective of this qualitative research is to better prepare for the intended quantitative research, which will be carried out in the doctoral thesis of one of the authors of this article.

\section{Research Subject and Object, Contact Method and Research Timetable}

The subject of this research was the CRM system and its problem areas. The objects of the research were small and medium-sized enterprises in the Moravian-Silesian Region. We selected companies providing services and contacted 30 representatives (via electronic devices) during June and July 2017. Seventeen respondents did not reply at all, three respondents were not interested and ten respondents were willing to undergo an interview with us. So, we introduced them the theme of the interview into details and made appointments with them.

\section{Random Sample and Characteristics of Respondents}

The minimum sample size was not mathematically formulated. In qualitative research, it is recommended to obtain respondents' answers till new ideas and opinions appear or in other words until we reach a state of theoretical saturation (Cooper and Schindler 2013, Bradley 2013, Reichel 2009).

The respondent sample included $70 \%$ of men and $30 \%$ of women. The respondents' position in the company is described in the Table 2. There were representatives of top management, the owners of companies, co-owners as well as directors and presidents of companies. Each interview took approximately 25 minutes. The representatives had different experience, but their average length of experience was from 4 to 20 years. In terms of closer business characteristics, according to statistical classification NACE, five respondents worked in the area of financial consultancy and five representatives worked for the field of accommodation and meals. The durations of individual interviews are also noted in Table 2. 
Table 2: Summary of positions and interview duration

\begin{tabular}{|c|c|c|c|}
\hline & tion in the company & Business field & Duration of individual interview (minutes) \\
\hline 1. & Owner & \multirow{5}{*}{ Financial consultancy } & $21: 36$ \\
\hline 2. & Co-owner & & 18:06 \\
\hline 3. & Director, president & & $22: 15$ \\
\hline 4. & Director & & $15: 05$ \\
\hline 5. & Director & & $23: 39$ \\
\hline 6. & Manager & \multirow{5}{*}{ Accommodation, meals } & $22: 28$ \\
\hline 7. & Owner & & $22: 00$ \\
\hline 8. & Director & & $13: 39$ \\
\hline 9. & Director & & $24: 00$ \\
\hline 1 & Manager & & $21: 50$ \\
\hline
\end{tabular}

Source: authors' work.

\section{Data Collection and Course of Interviews}

In the first phase, individual interviews were recorded using a voice recorder. We ensured the anonymity of our respondents. Each respondent had assigned a number and position. We conducted each interview the way preventing/avoiding interrupting the answers of representatives. If necessary, we asked additional questions.

In the second stage, we rewrote and printed individual interviews. The results were coded: the text was divided into shorter parts and each part was assigned to individual code or phrase. We got inspired from Strauss and Corbin and Hendl. Strauss and Corbin (1999, p. 43) claim that "During open coding, we work with individual parts of the text and research them very carefully. It enables us to compare differences and similarities." Hendl (1999, p.195) defines coding in qualitative research as follows: "Coding means constant comparison of phenomena, cases, terms etc. as well as formulating of questions related to the text (the process of continuous comparison)." At the same time, parts of the empirical material are assigned to the names or codes that are first of all closely related to the terms used in the text and thereafter become more and more abstract. We selected the topics which the respondent either mentioned as important or repetitive themes.

Now we will move to the analysis and our research results obtained from individual interviews in the selected companies.

\section{$4 \quad$ Analysis and qualitative research results}

We will gradually present all questions given to respondents during the individual interviews. After that, we will move to the qualitative analysis itself.

\subsection{Structure of interviews}

In total we formulated twelve questions for the purpose of the interview with respondents. The questions were divided into two thematic parts. The first part represented a wider context of customer relationship management and understanding of loyal customers. The main objective of the first part was to find out whether the respondents are interested in the given area. The second part was specialized in technology and operational activities in CRM. The inclusion of the technological aspects of CRM was considered important especially in connection with the current importance of technology usage in the development of companies. We wanted to find out if it was true in the SME too. 
The following questions were used for the purpose of this article:

1. How do you understand the term CRM?

2. How would you define a loyal customer?

3. How would you characterize a loyal customer?

4. How do you find out who is your loyal customer and what do you do to keep these customers?

5. What technology do you use to store information about customers?

6. Which problems and opportunities do you perceive as a part of CRM?

Now we will present important findings resulting from the answers of our respondents.

\subsection{Evaluation of questions}

How do you understand the term CRM? (question no. 1)

The purpose of the first question was to find out whether respondents understood the term CRM. Mostly the respondents agreed on 8 indicators that we see in Table 3. Companies commonly seek customer feedback - both positive and negative because it is the way how they can improve the range of goods and services which they offer. It also enables companies to increase customer satisfaction. The study done by IPSOS confirms that everyone doing business shall be interested in customer feedback because a dissatisfied customer will leave the company 1.7 times more likely than any other customer. ${ }^{4}$ The respondents believe that in enterprises should be created a company communication system that would be accessible to all employees because all employees should know the needs of customers and the possibilities of their satisfaction. To a certain extent these ideas correspond to the objectives of collaborative part of CRM. The respondents also highlighted the regularity of communication with customers. The company should communicate with the customer even after the sale in order to maintain relations with customers and to find other relevant information. Respondents also pointed out the supervision of communication with customers, although the interviewees confirmed that practically there is no supervision of communication with customers nowadays.

\section{How would you define a loyal customer? (question no. 2)}

Nowadays companies often focus on customer loyalty. It has a number of benefits including at least loyalty, long-term and repeated purchases. The inquirer tried to find out how the businesses perceived the customer loyalty and whether their views would be consistent or not. Respondents believed that a loyal customer has several characteristics: he/she is honest and provides feedback which enables companies to constantly improve their offers, quotations and activities. The latest findings on customer loyalty in the digital age show that businesses can secure brand loyalty of the customers based on trust. This is the results of Theingold Institute study, which is a reputable organization in the field of psychology and market research. ${ }^{5}$ And what are the factors of trust? It is transparency, understanding of customer needs, consistency of customer experience, willingness of employees, social responsibility of the company, psychological stimulation, amount of challenges, stimulating experiences, etc.

\section{How would you characterize a loyal customer? (question no. 3)}

Loyalty is different in B2B and B2C markets. Generally, B2C market has lower customer loyalty and customers more likely switch between businesses there. Davis et al. (2012) emphasize a higher loyalty in B2B market due to the need of greater level of certainty in

\footnotetext{
${ }^{4}$ Sazmová. Zpětná vazba k nezaplacení. Marketing Sales Média. s. 21. [online]. [2018-09-24]. Available from: https:// https://www.ipsos.com/sites/default/files/2017-12/11_leden.pdf.

${ }^{5}$ Study: skutečná loajalita je založena na důvěre. [online]. [2018-09-24]. Available from: https://www.mjournal.cz/cs/studie--skutecna-loajalita-zakazniku-je-zalozena-na-duvere_ss288x12170.html.
} 
business relationships. Respondents see the loyal customer as a symbol of business stability. A loyal customer represents motivation for both a top management and individual employees. The fact that the company has loyal customers shows them that they do their job well. In addition, companies believed that a loyal customer recommends the company to its friends, and thus attracts new customers for the company. A loyal customer is basically a part of the so-called reference market. The IPSOS research agency found that half of people regard to their previous experience while buying and one third of people accepts a piece of advice from somebody else from her/his surrounding. ${ }^{6}$

How do you find out who is your loyal customer and what do you do to keep these customers? (question no. 4)

Previous responses suggest that respondents perceive the importance of loyal customers, but do not measure loyalty. Companies try to identify loyal customers based on their feelings and impressions from their mutual communication. When a company identifies a key customer then it tries to keep him/her through various motivating activities. But even during the realization of these activities, it was possible to observe certain irregularity and randomness. Loyal customers are irregularly informed, e.g. about various marketing promotions or discounts. The unsystematic approach can be found even in sending birthday or Christmas greetings. Nevertheless, companies realize that this should not be an exceptional activity and that many companies focus on it more. Loyalty programs can be beneficial even for small businesses. According to surveys from 2016, an average Czech has 4 loyalty cards. ${ }^{7}$

We found smaller differences between respondents' opinions on financial consultancy services. Mandatory mobile-mediated communications are set at least once a year without a service offer, but this obligation is not checked by management. Two businesses implement training programs for their customers regarding financial literacy or organize events for families with children. Only two respondents did not organize any promotional events to build long-term relationships with loyal customers. This was case of companies which are not customer oriented.

\section{What technology do you use to store information about customers? (question no. 5)}

Technologies are one of CRM elements. The digital environment is still evolving. It offers new technologies and approaches to customers, which can improve the quality of customer relationships. In customer relationship management, technology is used not only to contact customers, but also to store information about them. In B2B and B2C markets can be found different approaches. In B2B market it is important to register the history of mutual deals and the history of communication with the customer. This is an overview of communications, mutual contracts, orders, invoices, or in other words the overview of all transactional data. Based on this evidence, the company can evaluate customer reliability and creditworthiness. In B2C may also have access to information from loyalty cards.

Addressed respondents mainly work with external or internal CRM software which was tailored to their specific requirements. The use of the software was confirmed especially by companies that were doing business in the field of financial consultancy. Companies offering accommodation and catering services mostly use simple spreadsheets and Excel. Some respondents showed a lack of trust in technology. On the one hand, respondents appreciated

\footnotetext{
${ }^{6}$ Sazmová. Zpětná vazba k nezaplacení. Marketing Sales Média. s. 21. [online]. [2018-09-24]. Available from: https:// https://www.ipsos.com/sites/default/files/2017-12/11_leden.pdf.

7 Věrnostní programy - jak vybudovat zákaznickou loajalitu. [online]. [2018-09-24]. Available from: https://www.nextvision.cz/blog/vernostni-programy-jak-vybudovat-zakaznickou-loajalitu.
} 
the effectiveness of technology, on the other hand, respondents were concerned about the loss of customer data. Therefore, all information is backed up on external storage devices or stored in paper form. Current security challenges deal with security issues and imperfections that may result in serious incidents in small and medium-sized enterprises. At present, even small and medium-sized organizations, which have been dealing with their infrastructure only through antivirus, will have to rethink their strategy. If they do not, the likelihood of having to face a leak or loss of important data is very high.

\section{Which problems and opportunities do you perceive as a part of CRM? (question no. 6)}

The most frequent reply of companies was that they have to deal with the lack of high-quality employees. The representatives also point out the lack of willingness of employees to communicate with customers, which is a certain barrier of relationships deepening. Particularly important are front-line employees. Kozak (2011) also finds the right selection of workers, who directly deal with customers, crucial. These employees greatly affect the satisfaction or dissatisfaction of individual customers. According to the latest CRM research done by our department, small and medium-sized enterprises prefer personal contact the most (Chromčáková, Starzyczná, Stoklasa 2017). The levels and quality of employee-customer relationships affected both customer satisfaction and loyalty. Another problem often mentioned by companies from the area of financial services is bureaucracy. They assume that administrative burden bothers both customers and employees.

Within this qualitative research we found some common features (key indicators) in respondents' answers. The results are stated in Table 3.

Table 3: Common key indicators of respondents' answers

\begin{tabular}{|l|l|}
\hline \multicolumn{1}{|c|}{ QUESTION } & \multicolumn{1}{|c|}{ KEY INDICATORS } \\
\hline 1. How do you understand the term CRM? & $\begin{array}{l}\text { Communication, surveys of customer needs, } \\
\text { feedback, communication system, regular } \\
\text { communication, supervision of communication, } \\
\text { customer satisfaction, awareness of employees }\end{array}$ \\
\hline 2. How would you define a loyal customer? & Loyal customer, frankness, feedback \\
\hline 3. How would you characterize a loyal customer? & Stability, feedback \\
\hline $\begin{array}{l}\text { 4. How do you find out who is your loyal customer } \\
\text { and what do you do to keep these customers? }\end{array}$ & $\begin{array}{l}\text { Intuition, irregular communication, mandatory } \\
\text { telephone communication }\end{array}$ \\
\hline $\begin{array}{l}\text { 5. What technology do you use to store information } \\
\text { about customers? }\end{array}$ & $\begin{array}{l}\text { Internal software, external software, Microsoft Excel, } \\
\text { external storage device; mistrust in technologies }\end{array}$ \\
\hline $\begin{array}{l}\text { 6. Which problems and opportunities do you } \\
\text { perceive as a part of CRM? }\end{array}$ & $\begin{array}{l}\text { Human resources, dissatisfaction of customers, } \\
\text { bureaucracy, customer recommendations, } \\
\text { technologies }\end{array}$ \\
\hline
\end{tabular}

Source: authors' work.

\section{Conclusion}

The objectives of this article are to introduce the theoretical debate about CRM and to introduce partial results which were obtained from the semi-standardised interview done with representatives of chosen enterprises. Research questions were focused on CRM, its basics, main problem and opportunity areas, customer loyalty and technological aspects of CRM. We conducted a qualitative research, which had a character of pre-research for a planned quantitative research.

The respondent answers showed some common features. The main consensus was in case of the research question 1. Here, the respondents agreed on 8 indicators related to communication, knowledge of needs, satisfaction of needs, customer satisfaction, regular communication and the need to implement a communication system and certain control 
mechanisms. The two latest mentioned indicators are paradoxical as businesses are aware of their importance, but hardly use them in practice.

Another significant consensus was proven in the area of characteristic of loyal customers. Some authors note that the term loyal customer is understood as a regular customer who also provides feedback to the company. Individual respondents perceive the loyal customer as a positive advertising tool, which is a sign of the company stability. Moreover, the respondents are aware of the fact that CRM can attract new customers (from competition) if loyal customers recommend them the company. Relationship management can also increase the number of satisfied customers (Curry and Kolla 2004).

Technologies are used to store information about customers, so they are a significant contribution for companies. In addition, respondents agree that they are afraid of the potential data loss, thus they often back up data on external storage devices or in paper form. As it has been previously mentioned, respondents use different software for storage of important data. The respondents believe that the constantly developing software positively affects the productivity of work and therefore it is seen as a potential opportunity for the area of CRM.

The qualitative research presented in this article is a basis for the future research activities dealing with the assessment of the level of customer relationship management in SME. The planned research will use quantitative methods and a questionnaire - the questionnaire will include the individual parts of CRM architecture and the use of the individual CRM elements and will be sent to SME in the Moravian-Silesian region. The future quantitative research will be carried out in the doctoral thesis of one of the authors of this article.

\section{Acknowledgement}

The article was prepared based on research conducted in the context of ensuring the sustainability of the project OP VK Reg. no. CZ.1.07/2.3.00/20.0016 "Targeted research in the field of small and medium businesses to achieve a competitive knowledge economy" and student grant competition project SGS/7/2017: "Acceptance of technology from the perspective of marketing tools."

\section{References}

[1] BRADLEY, N., 2013. Marketing research: Tools and techniques, 3rd Ed. Oxford: Oxford University Press.

[2] BUTTLE, F., 2009. Customer Relationship Management Concepts and Technologies. Oxford: Elsevier.

[3] BUTTLE, F. and S. MAKLAN, 2015. Customer relationship management: concepts and technologies, 3rd Ed. Routledge, Taylor and Francis Group, London, U.K

[4] COLTMAN, T. et al., 2011. Customer relationship management and firm performance. Journal of Information Technology, vol. 26, issue 3, pp. 205-219.

[5] COOPER, D. and P. SCHINDLER, 2013. Business Research Methods. 12th Ed. New York: McGraw-Hill.

[6] CURRY, A. and E. KOULU, 2004. Evaluating CRM to contribute to TQM improvement: a cross-case comparison. The TQM magazine, vol. 16, issue 5, pp. 314 24. 
[7] DAY, G. S. and R. WENSLEY, 1983. Marketing theory with strategic orientation. Journal of Marketing, vol. 47, issue 4, pp. 79-89.

[8] DOHNAL, J., 2002. Customer relationship management. Praha: Grada Publishing.

[9] FICKEL, L., 1999. Know your customer. CIO Magazine, vol. 12, issue 21, pp. 62-72.

[10] GREENBERG, P., 2001. CRM at the speed of light: capturing and keeping customer in Internet Real time. 2nd Ed. Amsterdam: Elsevier.

[11] GREENBERG, P., 2010. The impact of CRM 2.0 on customer insight. Journal of Business and Industrial Marketing, vol. 25, issue 6, pp. 410-419.

[12] HENDL, J., 1999. Úvod do kvalitativního výzkumu. Praha: Karolinum.

[13] CHLEBOVSKÝ, V., 2005. CRM-Řizení vztahů se zákazníky. 1st Ed. Brno: Computer Press

[14] CHRISTOPHER, M., A. PAYNE and D. BALLANTYN, 2002. Relationship Marketing. Creating Stakeholder Value. Oxford: Elsevier Ltd.

[15] CHROMČÁKOVÁ, A., H. STARZYCZNÁ and M. STOKLASA, 2017. The level of selected CRM areas in small and medium sized enterprises in Czech republic. Forum Scientiae Oeconomia, vol. 5, issue 4, pp.59-70.

[16] KOTLER, P. and G. ARMSTRONG, 2004. Marketing. Praha: Grada Publishing.

[17] KOTLER, P., et al., 2007. Moderní marketing. Praha: Victoria Publishing.

[18] KOTLER, P. and K. L. KELLER, 2013. Marketing Management. Praha: Grada Publishing.

[19] KOTLER, P., H. KARTAJAYA and I. SETIAWAN, 2016. Marketing 4.0: Moving from Traditional to Digital. 1. Ed. Viley.

[20] KUMAR, V. and J. W. REINARTZ, 2016. Creating enduring customer value. Journal of Marketing, vol. 80, issue 0, pp. 36-68.

[21] LOŠŤÁKOVÁ, H. et al., 2009. Diferencované ř́zení vztahů se zákazníky. Praha: Grada Publishing.

[22] LOŠŤÁKOVÁ, H., 2017. Nástroje posilování vztahů se zákazníky na B2B trhu. Praha: Grada Publishing.

[23] LEHTINEN, J., 2007. Aktivní CRM - Řízení vztahů se zákazníky. Praha: Grada Publishing.

[24] LEVITT, T., 1960. Marketing Myopia. Harvard Business Review, vol. 38, issue 2, pp. 45-60.

[25] MEFFERT, H., 1996. Marketing management. Praha: Grada publishing.

[26] PAYNE, A. and P. FROW, 2004. The role of multi channel integration in customer relationship management. Industrial Marketing Management, vol. 33, issue 6, pp. 527538.

[27] PAYNE, A., 2007. Handbook of CRM. Oxford: Elsevier Ltd.

[28] PAYNE, A., and P. FROW, 2013. Strategic Customer Management: Integrating Relationship Marketing and CRM. Cambridge University Press, Cambridge.

[29] PEELEN, E., 2005. Customer Relationship Management. Essex: Pearson Education Limited. 
[30] PENKALA, J., 2018. Úvod do omnichannel. Proč je budoucností prodeje? [online]. [2018-07-25]. Available from: https://blog.acomware.cz/uvod-do-omnichannel-proc-jebudoucnosti-prodeje/.

[31] REICHER, R. and Á. SZEGHEGYI, 2015. Factors Affecting the Selection and Implementation of a Customer Relationship Management (CRM) Process. Acta Polytechnica Hungarica, vol. 12, issue 4, pp. 183-200.

[32] REICHEL, J., 2009. Kapitoly Metodologie sociálních výzkumů. 1st Ed. Praha: Grada Publishing.

[33] SAZMOVÁ, L., 2017. Zpětná vazba k nezaplacení. Marketing Sales Média. [online]. [2018-09-24]. Available from: https:// https://www.ipsos.com/sites/default/files/201712/11_leden.pdf.

[34] STARZYCZNÁ, H., KAUEROVÁ et al., 2007. Metodologie marketing vztahů a její postavení $v$ rámci strategického marketing a ř́zení vztahů se zákazníkem (CRM) Praktické využití. Karviná: OPF-SU.

[35] STRAUSS, A., a J. CORBINOVÁ, 1999. Základy kvalitativního výzkumu: postupy a techniky zakotvené teorie. Boskovice: Albert.

[36] TORGGLER, M., 2008. The Functionality and Usage of CRM Systems. World academy of science: Engineerig and Technology, vol. 2, issue 5, pp. 301-309

[37] WESSLING, H., 2002. Aktivní vztah k zákaznikům pomocí CRM. Strategie, praktické príklady a scénáré Praha: Grada Publishing. 